\title{
ONLINE TEACHING ENGLISH FOR BUSINESS AND ECONOMICS IN THE TIME OF PANDEMICS
}

\author{
Carina Ionela BRANZILA** \\ a) Alexandru Ioan Cuza University, Faculty of Economics and Business \\ Administration, Iaşi, Romania
}

Please cite this article as:

Article History:

Branzila, C.I., 2020. Online teaching English for Received: 12 October 2020 Business and Economics in the time of pandemics. Accepted: 6 November 2020 Review of Economic Studies and Research Virgil Madgearu, 13(2), pp.27-36.

doi: 10.24193/RVM.2020.13.58.

Abstract: This article looks into the specifics of teaching in these challenging times, particularly after the outbreak of the Covid pandemics early in 2020 and the lockdown that followed, which forced the general migration of teaching into online. Teaching with the use of technology, already in high demand worldwide, has soared during this period, having its detractors as well as its committed followers. The article looks into recent research on how technology impacts the learning process and how this might develop in the future, influencing teachers, students, campus-based teaching and education in general in the following years. There are obviously minuses and pluses to online teaching and learning; this article will discuss some of them, with practical examples and information from the particular context of higher education teaching in Romania.

Key words: online teaching; e-learning; education; technology; future JEL Classification: $A 1 ; A 2 ; A 3 ; Y 8$

(C) 2020 Alma Mater Publishing House. All rights reserved.

* Corresponding author. E-mail address: carinabranzila@gmail.com. 


\section{References:}

1. Alessi, S.M. and Trollip, S.R., 1985. Computer-based instruction: methods and development. Englewood Cliffs, NJ: Prentice-Hall.

2. Conole, G. and Culver, J., 2009. Cloudworks: social networking for learning design. Australasian Journal of Educational Technology, 25(5), pp.763-782.

3. Cross, J., 2004. An informal history of eLearning. on The Horizon, 12, pp.103-110. https://doi.org/10.1108/10748120410555340.

4. E-Learning Fundamentals, 2020. History of e-Learning. [online] Available at: <http://www.leerbeleving.nl/wbts/1/history_of_ elearning.html $>$ [Accessed 10 October 2020].

5. Illich, I., 1983. Deschooling Society. New York: Harper Colophon, pp.76-77.

6. Masie, E., 2020. Masie Center. Learning, Technology \& Innovation. [online] Available at: <http://www.masie.com > [Accessed 3 October 2020].

7. McAvinia, C., 2016. Online Learning and its Users: Lessons for Higher Education. Chandos Publishing.

8. Pagliaro, L.A., 1983. The history and development of CAI: 19261981, an overview. The Alberta Journal of Educational Research, 29(1), pp.75-84. 